\title{
PENGARUH PROGRAM PELATIHAN DAN KOHESIVITAS TERHADAP KINERJA PENGAJAR DI LEMBAGA PENDIDIKAN XYZ
}

\author{
THE EFFECTS OF TRAINING PROGRAM AND COHESIVENESS ON \\ TEACHER JOB PERFORMANCE IN XYZ EDUCATIONAL INSTITUTIONS
}

\author{
Nurul Anisya*)1, Nurmala K Panjaitan**), dan Sadikin Kuswanto*) \\ ${ }^{*}$ Sekolah Bisnis, IPB University \\ Jl. Raya Pajajaran, Bogor 16151 \\ ${ }^{* *}$ Departemen Sains Komunikasi dan Pengembangan Masyarakat, Fakultas Ekologi Manusia, IPB University \\ Jl. Darmaga, Kampus Darmaga Bogor 16680
}

\begin{abstract}
The training program is an effort to improve performance. Excellent performance requires good cooperation from every employee. This study aims to investigate the effect of training programs and cohesiveness on teacher performance. This study used descriptive analysis and quantitative data. Data were processed using the structural equation model (SEM) based on partial least square (PLS) estimation. The study used questionnaires to collect data. The results show the training program significantly influenced the level of cohesiveness of the teacher. Furthermore, training programs significantly influenced teacher performance. The formation of teacher performance variables was influenced by the teacher's social relation dimension. Hence, cohesiveness significantly affected teacher performance. The formation of cohesiveness variable was influenced by individual interest in the group assignment dimension.
\end{abstract}

Keywords: group, job performance, cohesiveness, PLS, training program

\begin{abstract}
Abstrak: Program pelatihan merupakan upaya untuk meningkatkan kinerja. Kinerja yang baik membutuhkan kerja sama yang baik dari setiap karyawan. Penelitian ini bertujuan untuk mengetahui pengaruh program pelatihan dan kekompakan terhadap kinerja guru. Penelitian ini menggunakan analisis deskriptif dan data kuantitatif. Data diolah menggunakan structural equation modelling (SEM) menggunakan metode partial least square (PLS). Teknik pengumpulan data yang digunakan dalam penelitian ini adalah teknik kuesioner. Hasil penelitian ini dapat disimpulkan bahwa program pelatihan dapat mempengaruhi tingkat kohesivitas guru secara signifikan. Program pelatihan juga secara signifikan mempengaruhi kinerja guru. Dimensi yang paling mempengaruhi pembentukan variabel kinerja guru adalah hubungan sosial guru. Kohesivitas pengajar dapat secara signifikan mempengaruhi kinerja pengajar. Dimensi yang paling mempengaruhi pembentukan variabel keterpaduan adalah dimensi ketertarikan individu dalam tugas kelompok.
\end{abstract}

Kata kunci: kelompok, kinerja, kohesivitas, pls, program pelatihan

\footnotetext{
${ }^{1}$ Corresponding author:

Email: nisa.nurulanisya@gmail.com
} 


\section{PENDAHULUAN}

Tenaga kerja merupakan sumber daya yang memiliki peran aktif dalam berjalannya suatu perusahaan. Pada Lembaga Pendidikan pengajar merupakan sumber daya manusia yang memiliki peran penting dalam berjalannya Lembaga tersebut. Pengajar pada era perkembangan teknologi informasi saat ini dituntut untuk lebih responsif terhadap perkembangan ilmu pengetahuan. Oleh karena itu, lembaga-lembaga pendidikan di Indonesia dirasa perlu membentuk program-program pelatihan lainnya guna terciptanya peningkatan mutu pendidikan yang lebih baik di Indonesia.

Lembaga pendidikan XYZ merupakan lembaga pendidikan yang memiliki perhatian khusus pada program-program pelatihan untuk tenaga pengajarnya. Program pelatihan yang terdapat di Lembaga Pendidikan ini diawali dengan initial training bagi pengajar baru. Program pelatihan selanjutnya yaitu program personal development yang diadakan setiap bulannya. Programprogram pelatihan tersebut ditujukan agar kinerja pengajar dari lembaga pendidikan ini dapat terus meningkat. Program pelatihan meliputi pengkajian hasil penelitian terbaru dibidang pendidikan, pelatihan teamwork, pelatihan metode pengajaran dan sebagainya. Namun, dalam lembaga pendidikan ini belum diteliti bagaimana efektivitas program pelatihan tersebut. Selain itu, belum diketahui pengaruh program pelatihan dan kohesivitas terhadap kinerja pengajar.

Program pelatihan merupakan suatu investasi yang tidak murah bagi perusahaan. Investasi yang harus dibayar oleh perusahaan untuk program pelatihan bukan hanya berbentuk materi saja. Namun, waktu, fasilitas dan tentunya pemikiran untuk merancang suatu program pelatihan. Oleh karena itu, perusahaan perlu menilai dan menelaah lebih jauh tentang program pelatihan yang dimilikinya. Tuhumena et al. (2017) menyatakan berdasarkan penelitian yang dilakukannya pelatihan dan motivasi kerja secara simultan memengaruhi kinerja karyawan. Dahmiri dan Sakta (2014) juga menyatakan pendapat yang sama bahwa pelatihan dapat memengaruhi kinerja pegawai dengan nilai koefisien determinasi ( $\mathrm{R}$ square) sebesar 0,253. Julianry et al. (2017) dalam penelitiannya menyatakan, pelatihan berpengaruh positif signifikan terhadap kinerja karyawan dan perusahaan.
Kohesivitas pada kelompok ditandai dengan keterikatan, kesamaan tujuan dan perasaan saling berkomunikasi diantara anggota kelompok. Noviati dan Zipi (2013) melalui penelitiannya menyatakan bahwa pelatihan dapat memengaruhi tingkat kohesivitas kelompok. Pendapat lain mengenai kohesivitas juga disampaikan oleh Purwaningtyastuti et al. (2012) yaitu terdapat korelasi antara komitmen organisasi dengan kohesivitas.

Lingkup pembahasan dalam penelitian ini dibatasi pada manajemen Sumber Daya Manusia yang akan terfokus pada pengaruh program pelatihan, tingkat kohesivitas, dan kinerja pengajar. Lingkup pembahasan ini dilakukan agar penelitan ini dapat fokus dalam menjawab pemasalahan yang terdapat pada lembaga pendidikan XYZ dan diharapkan dapat sesuai dengan tujuan penelitian. Tujuan dari penelitian ini adalah sebagai berikut: Menganalisis tingkat kohesivitas pengajar lembaga Pendidikan XYZ; Menganalisis pengaruh program pelatihan terhadap kohesivitas pengajar; Menganalisis pengaruh program pelatihan dan kohesivitas terhadap kinerja pengajar.

\section{METODE PENELITIAN}

Penelitian dilakukan pada dua depatemen dari Lembaga Pendidikan XYZ yang berlokasi di Jakarta Selatan. Pemilihan lokasi dan lakukan secara purposive dengan mempertimbangkan intensitas waktu pelatihan yang dimiliki oleh Lembaga Pendidikan ini. Waktu pengambilan data dilakukan pada bulan Agustus sampai bulan September 2018. Responden dipilih secara sesus. Responden merupakan tenaga pengajar dari lembaga pendidikan XYZ. Pengajar yang dapat menjadi responden dalam penelitian ini adalah pengajar yang telah bekeja pada Lembaga Pendidikan tersebut paling lambat 1 tahun dan telah mengikuti pelatihan.

Analisis yang digunakan pada penelitian ini adalah analisis Sructural Equation Modelling (SEM) dengan metode Partial Least Squares (PLS). SEM dianggap mampu menjawab pertanyaan penelitian tersebut karena analisis ini mempunyai kemampuan untuk mengestimasi hubungan antar variabel yang bersifat multiple relationship (Yamin dan Kurniawan, 2009). Analisis SEM dalam penelitian ini diharapkan dapat menjawab pertanyaan-pertanyaan penelitian seperti, hubungan-hubungan antar variabel, seberapa besar pengaruh variabel terhadap variabel lainnya, dan 
variabel manakah yang memiliki pengaruh yang paling besar pada penelitian ini. Perangkat lunak SmartPLS dipilih karena data yang digunakan pada penelitian ini jumlahnya tidak bersar dan terbatas. Tahapan analisis yang akan dilakukan yaitu, merancang model struktural, merancang model pengukuran, mengkonstruksi diagram jalur, evaluasi model, dan pengujian hipotesis dan interpretasi (Ghozali, 2011). Penelitian ini menggunakan tiga variabel yang terdiri dari, program pelatihan, kohesivitas dan kinerja.

Hubungan antarvariabel dalam penelitian ini dapat dijelaskan pada kerangka pemikiran konseptual yang dapat dilihat pada Gambar 1. Variabel program pelatihan diadaptasi dari Kirkpatrick (2006) yang mengembangkan model evaluasi efektivitas program pelatihan. Model evalasi tersebut dikembangkan menjadi indikator - indikator yang dapat mendukung variabel tersebut. Indikator tersebut yaitu, materi pelatihan, metode pelatihan, instruktur pelatihan, waktu pelatihan dan fasilitas yang digunakan saat pelatihan. Variabel kohesivitas kelompok diadaptasi dari Carron et al. (2009) yang mengembangkan empat dimensi dalam kohesivitas. Keempat dimensi tersebut yaitu, keterpaduan kelompok dalam tugas, keterpaduan kelompok dalam sosial, ketertarikan individual pada tugas kelompok, dan ketertarikkan individual pada kelompok sosial. Variabel selanjutnya dalam penelitian ini yaitu variabel kinerja pengajar. Variabel ini diadaptasi dari penilaian kinerja pengajar pada Peraturan Menteri Pendidikan Nomor 16 tahun 2007. Ditjen PMPTK (2008) mengembangkan standar kualifikasi kompetensi pengajar pada empat kompetensi utama yaitu, kompetensi pedagogik, kepribadian pendidik, hubungan sosial, dan profesional.

Hipotesis yang dirumuskan dalam penelitian ini adalah diduga kohesivitas pengajar tinggi; diduga program pelatihan berpengaruh terhadap kohesivitas pengajar; diduga program pelatihan dan kohesivitas kelompok berpengaruh terhadap kinerja pengajar.

\section{HASIL}

\section{Penilaian Responden terhadap Program Pelatihan di Lembaga Pendidikan XYZ}

Pelatihan merupakan kegiatan yang rutin dilakukan oleh Lembaga pendidikan ini setiap bulannya. Agenda pelatihan yang dilakukan dapat beragam, sesuai dengan kebutuhan dan urgensi dari pengajar. Tingkat penilaian responden terhadap pelatihan dibagi menjadi lima dimensi. Kelima dimensi tersebut yaitu, materi, metode, instruktur, waktu dan fasilitas pelatihan. Penilaian pelatihan dibagi menjadi tiga kategori yaitu, rendah dengan penilaian skala likert 1-2 (sangat tidak setuju dan tidak setuju), sedang dengan penilaian skala likert 3 (ragu - ragu), dan tinggi dengan penilaian skala likert 4-5 (setuju dan sangat setuju).
Program pelatihan
1. Materi
2. Metode
3. Instruktur
4. Waktu pelatihan
5. Fasilitas pendukung

Kohesivitas

1. Keterpaduan kelompok dalam tugas.

2. Keterpaduan kelompok dalam sosial.

3. Ketertarikan individual pada tugas kelompok.

4. Ketertarikan individual pada kelompok sosial

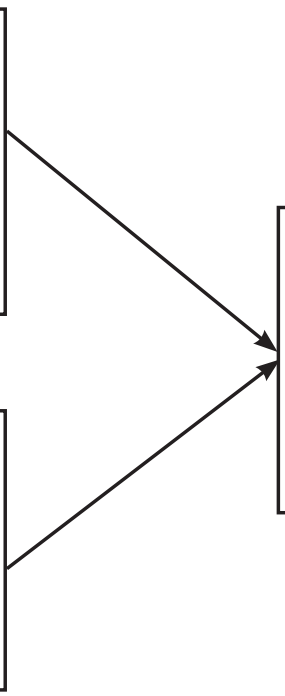

Kinerja

1. Kompetensi pedagogis.

2. Kepribadian pendidik.

3. Hubungan sosial.

4. Profesional.

Gambar 1. Kerangka pemikirian penelitian 
Tabel 1 menunjukkan hasil penilaian terhadap dimensi materi dan metode mendapatkan persentase $67 \%$ dan $62 \%$. Hal ini menunjukkan materi dan metode yang digunakan untuk program pelatihan di Lembaga Pendidikan XYZ dinilai memuaskan responden dengan demikian perusahaan perlu mempertahankan hal ini. Responden menilai materi yang disampaikan pada pelatihan dinilai bermanfaat dalam meningkatkan kualitas pekerjaan sehari-hari, dapat meningkatkan kerjasama, dan juga dapat membagun keakraban diantara peserta pelatihan. Pada Lembaga Pendidikan $\mathrm{XYZ}$ pemilihan materi pelatihan disesuaikan dengan kebutuhan pengajar. Kepala sekolah melakukan monitoring kepada pengajar-pengajar dalam grade -nya untuk menentukan kebutuhan materi pelatihan yang akan diberikan.

Tabel 1. Penilaian responden terhadap program pelatihan

\begin{tabular}{lcccccccc}
\hline \multirow{2}{*}{ Dimensi } & \multicolumn{9}{c}{ Kategori } & \multirow{2}{*}{ Jumlah } \\
\cline { 2 - 8 } & \multicolumn{1}{c}{ Rendah } & \multicolumn{2}{c}{ Sedang } & \multicolumn{2}{c}{ Tinggi } & & \\
\cline { 2 - 8 } & $\mathrm{n}$ & $\%$ & $\mathrm{n}$ & $\%$ & $\mathrm{n}$ & $\%$ & $\mathrm{~N}$ & $\%$ \\
\hline Materi & 1 & 2 & 13 & 31 & 28 & 67 & 42 & 100 \\
Metode & 0 & 0 & 16 & 38 & 26 & 62 & 42 & 100 \\
Instruktur & 2 & 5 & 25 & 60 & 15 & 36 & 42 & 100 \\
Waktu & 5 & 12 & 15 & 36 & 22 & 52 & 42 & 100 \\
Fasilitas & 0 & 0 & 14 & 33 & 28 & 67 & 42 & 100 \\
\hline
\end{tabular}

Hasil penilaian dengan persentase sedang yaitu pada dimensi instruktur. Pada dimensi ini bila disimpulkan responden menilai metode yang digunakan instruktur pelatihan perlu ditingkatkan dan dikaji kembali sehingga, dapat mudah dimengerti oleh peserta pelatihan. Responden juga menilai bahwa instruktur pelatihan perlu meningkatkan kemampuannya dalam hal membagun situasi yang akrab dalam kelompok serta membuat peserta pelatihan saling berkomunikasi dan berdiskusi. Program pelatihan di Lembaga Pendidikan XYZ memiliki instruktur pelatihan yang beragam.
Instruktur bukan hanya kepala sekolah, tetapi guru, psikolog maupun para ahli dibidang lain juga dapat menjadi instruktur dari pelatihan ini.

Hasil penilaian responden terhadap waktu dan fasilitas pendukung program pelatihan dikategorikan baik. Responden menilai waktu pelaksanaan pelatihan dinilai baik sehingga peserta dapat memahami materi yang disampaikan selain itu, waktu pelatihan juga di nilai efektif. Pada dimensi fasilitas pendukung, responden menilai alat bantu dan ruang belajar yang digunakan untuk pelatihan dinilai sudah baik. Lembaga Pendidikan XYZ memiliki ruangan dan perlengkapan tersendiri guna mendukung terlaksananya program pelatihan. Perlengkapan tersebut meliputi proyektor, filp cart, ruang belajar, teater dan sebagainya. Waktu pelaksanaan program pelatihan dilakukan setiap bulannya setelah program belajar mengajar selesai.

\section{Tingkat Kohesivitas Pengajar Lembaga Pendidikan XYZ}

Penelitian ini melakukan penilaian kohesivitas pengajar Lembaga Pendidikan XYZ. Dimensi kohesivitas yang digunakan terdiri dari keterpaduan kelompok dalam tugas, keterpaduan kelompok dalam sosial, ketertarikan individual pada tugas kelompok, dan ketertarikan individual pada kelompok sosial.

Tabel 2 menjelaskan penilaian responden terhadap kohesivitas pada Lembaga Pendidikan XYZ. Jika dilihat secara keseluruhan pada Tabel 2, penilaian responden terhadap Lembaga Pendidikan XYZ tergolong sedang ke tinggi. Hal ini ditunjukkan terdapat dua dimensi yang dikategorikan tinggi yaitu keterpaduan kelompok dalam tugas dan ketertarikan individual pada tugas kelompok. Sedangkan, pada kategori sedang juga terdapat dua dimensi yaitu, keterpaduan kelompok dalam sosial dan ketertarikan individual pada kelompok sosial.

Tabel 2. Penilaian responden terhadap kohesivitas pengajar

\begin{tabular}{|c|c|c|c|c|c|c|c|c|}
\hline \multirow{3}{*}{ Dimensi } & \multicolumn{6}{|c|}{ Kategori } & \multirow{2}{*}{\multicolumn{2}{|c|}{ Jumlah }} \\
\hline & \multicolumn{2}{|c|}{ Rendah } & \multicolumn{2}{|c|}{ Sedang } & \multicolumn{2}{|c|}{ Tinggi } & & \\
\hline & $\mathrm{n}$ & $\%$ & $\mathrm{n}$ & $\%$ & $\mathrm{n}$ & $\%$ & $\mathrm{~N}$ & $\%$ \\
\hline Keterpaduan kelompok dalam tugas & 0 & 0 & 14 & 33 & 28 & 67 & 42 & 100 \\
\hline Keterpaduan kelompok dalam sosial & 2 & 5 & 21 & 50 & 19 & 45 & 42 & 100 \\
\hline Ketertarikan individual pada tugas kelompok & 1 & 2 & 16 & 38 & 25 & 60 & 42 & 100 \\
\hline Ketertarikan individual pada kelompok sosial & 6 & 14 & 19 & 45 & 17 & 40 & 42 & 100 \\
\hline
\end{tabular}


Kedua dimensi dengan kategori tinggi tersebut memiliki kesamaan yaitu keduanya memiliki keterikatan dengan tugas. Dengan demikian, responden menilai tugas memiliki peran yang dapat mendorong keterpaduan dalam suatu kelompok. Selain itu tugas juga dinilai memiliki daya tarik bagi individu kedalam kelompok. Lembaga Pendidikan XYZ memiliki program-program kerja yang membuat pengajar dapat bekerjasama dengan departemen lain. Namun, jika tidak dikaitkan dengan tugas, kohesivitas pada Lembaga Pendidikan ini dinilai dengan kategori sedang sampai rendah. Wibowo (2013) menyatakan, kelompok yang tergolong memiliki kohesivitas rendah yaitu, kelompok yang tidak saling menyukai antar anggota kelompok bahkan bekerja dengan tujuan yang bertolak belakang.

Kondisi tingkat kohesivitas yang dinilai sedang pada aspek sosial ditunjukkan dengan terdapatnya beberapa keresahan pengajar terhadap pengajar lain yang disampaikan kepada manajemen terkait.

“... adabeberapapengajaryangmulaimelaporkan mereka merasa tidak nyaman dengan pengajar lainnya. Memang kita tidak bisa memaksakan si A harus berteman dengan si B tapi saya rasa jika hal ini dibiarkan akan terjadi konflik sosial yang lebih besar. Saya maunya kita semua bisa maju bersama. Oleh karena itu, perlu dilakukan upayaupaya untuk membangun keakraban tersebut..." (IR Kepala Sekolah Lembaga XYZ).

Upaya yang dilakukan Lembaga Pendidikan XYZ untuk meningkatkan keakraban diantara pengajarnya yaitu dengan melakukan pelatihan team building yang dilakukan pada awal and pertengahan tahun ajaran. Namun, melihat kondisi penilaian responden pada Tabel 1 upaya tersebut dirasa belum cukup untuk meningkatkan keakraban pengajar pada aspek sosial. Lembaga Pendidikan ini perlu melakukan upaya lain untuk meningkatkan keakraban diantara pengajar. Pengajar perlu diberikan kesempatan untuk bertemu, berkomunikasi, dan bertukar pendapat dengan pengajar lainnya guna terbangunnya kohesivitas diantara mereka.

\section{Uji Model Struktural (Inner Model)}

Model struktural adalah model yang menghubungkan variabel laten exogenous dengan variabel laten endogenous atau hubungan variabel endogenous dengan variabel endogenous lainnya. Pada uji model struktural dilakukan dengan menganalisis nilai koefisien determinasi (R2). Koefisien determinan (R2) digunakan untuk mengukur tingkat variasi perubahan variabel independent terhadap variabel dependen.

Tabel 3 menunjukkan nilai R2 pada variabel kinerja yaitu 0,63 . Artinya, sebesar $63 \%$ variabel ini dapat dijelaskan oleh variabel pelatihan dan kohesivitas, selebihnya dapat dijelaskan oleh faktor lain diluar model. Pada variabel kinerja terdapat $37 \%$ faktor lain di luar model dapat menjelaskan variabel ini. Pernyataan ini didukung oleh penelitian Aboazoum et al. (2015) yang menganalisis faktor-faktor yang memengaruhi kinerja pegawai. Hasil penelitian tersebut menyatakan bahwa kinerja pegawai secara signifikan dipengaruhi oleh budaya organisasi, kepuasan kerja, dan juga pelatihan. Irawan et al. (2015) juga menyatakan memlalui penelitiannya faktor individu, faktor psikologi dan faktor organisasi berpengaruh secara langsung terhadap kinerja. Nilai R2 pada variabel kohesivitas, yaitu 0,56. Nilai ini menunjukkan sebesar $56 \%$ variabel ini dapat dijelaskan oleh variabel pelatihan, selebihnya dapat dijelaskan oleh faktor lain diluar model.

Tabel 3 Nilai Koefisien Determinan

\begin{tabular}{ll}
\hline & R Square \\
\hline Kinerja & 0,630555 \\
Kohesivitas & 0,564654 \\
\hline
\end{tabular}

\section{Pengaruh Program Pelatihan terhadap Kohesivitas Pengajar}

Nilai koefiesien jalur yang didapat dari analisis SEM digunakan untuk menentukan pengaruh antar variabel. Pada Tabel 4 dapat dilihat hasil dari perhitungan tersebut. Kriteria t-statistik signifikan adalah jika, nilai t-statistik $>2,018$, dengan total db sebesar 42, dan nilai alpha sebesar 0,05 .

Hasil pengujian pada Table 4 diperoleh nilai t-statistik sebesar 16,822061. Nilai tersebut lebih besar jika dibandingkan dengan nilai t-tabel 2,018. Sehingga dapat disimpulkan, program pelatihan yang dilakukan pada Lembaga pendidikan XYZ berpengaruh positif dan signifikan terhadap kohesivitas pengajar. Hal ini dapat terbentuk karena, dalam pelatihan pada Lembaga Pendidikan XYZ instruktur yang menjadi narasumber dapat beragam salah satunya pengajar itu sendiri. Hal ini lah yang membuat keakraban dapat terbentuk karena antara pengajar saling berbagi ilmu. Hasil penelitian ini didukung dengan beberapa hasil penelitian sebelumnya. 
Hasil penelitian Setiawati dan Riyono (2018) dan Widiantoro et al. (2017), menyatakan bahwa pelatihan komunikasi interpersonal dapat meningkatkan kohesivitas kelompok karyawan.

Nilai koefisien jalur pada variabel pengaruh program pelatihan terhadap kohesivitas pengajar merupakan nilai yang tertinggi diantara variabel lainnya, yaitu 0,751435 . Artinya, pada Lembaga Pendidikan XYZ, program pelatihan lebih banyak memengaruhi kohesivitas pengajar bila dibandingkan dengan pengaruhnya terhadap variabel kinerja. Sistem pembelajaran yang digunakan oleh Lembaga Pendidikan XYZ pada setiap program pelatihan yang dilakukannya secara signifikan dapat memengaruhi tingkat kohesivitas dari pengajar. Sistem pembelajaran pada Lembaga Pendidikan XYZ membuat para pengajar saling berkomunikasi dan bertukar pendapat. Pelatihan yang pada Lembaga Pendidikan XYZ dilakukan satu sampai dengan dua kali dalam setiap bulannya.

\section{Pengaruh Program Pelatihan dan Kohesivitas terhadap Kinerja Pengajar}

Tabel 5 menunjukkan hasil perhitungan nilai koefisien jalur pada variabel pelatihan dan kohesivitas terhadap variabel kinerja. Nilai t-statistik variabel pelatihan terhadap kinerja yaitu 3,180727. Bila dibandingkan dengan nilai t-tabel, nilai tersebut lebih besar dari 2,108. Maka, dapat disimpulkan terdapat pengaruh yang positif dan signifikan dari program pelatihan dan kinerja pengajar.

Hasil yang sama juga diperoleh oleh beberapa penelitian sebelumnya yang meneliti tentang pengaruh pendidikan dan pelatihan terhadap kinerja karyawan.
Penelitian Pakpahan et al. (2011), Sahanggamu dan Mandey (2014), dan Wiratama dan Sintaasih (2013) menunjukkan bahwa terdapat pengaruh yang positif dan signifikan antara pendidikan dan pelatihan terhadap kinerja pegawai. Palupi et al. (2017) juga menyatakan bahwa program pelatihan mampu memengaruhi secara signifikan terhadap kinerja peserta pelatihan.

Pada Lembaga Pendidikan XYZ penilaian kinerja pengajar dilakukan dengan tiga tahapan. Tahapan pertama adalah tahapan perencanaan kinerja, tahapan ini dilakukan sebelum tahun ajaran baru dimulai. Tahap perencanaan dilakukan guna mentukan tujuan pencapaian / target yang akan dicapai oleh pengajar pada tahun ajaran yang akan datang. Tahapan ini kemudian dilanjutkan dengan tahapan monitoring. Pada tahapan monitoring dilakukan program-program pelatihan guna mendukung kinerja pengajar. Tahapan terakhir adalah tahap assessment (penilaian kinerja). Sistem penilaian yang dilakukan pada Lembaga Pendidikan ini adalah dengan mengirimkan form yang wajib diisi oleh pengajar kemudian dikonfirmasi kembali dengan pimpinan (Kepala sekolah).

Hasil uji t pada variabel kohesivitas terhadap variabel kinerja menunjukkan t-statistik sebesar 6,731228. Dengan demikian nilai t-statistik lebih besar dari t-tabel, yaitu 2,018. Sehingga dapat disimpulkan terdapat pengaruh yang signifikan dari kohesivitas terhadap kinerja pengajar. Hasil tersebut didukung oleh beberapa penelitian sebelumnya yang meneliti tentang kohesivitas dan kinerja karyawan. Banwo et al. (2015) dan Nasir et al. (2017) melalui penelitiannya menyatakan, kelompok yang tingkat kohesivitas nya tinggi, berpengaruh terhadap kelompok yang memiliki kinerja yang baik.

Tabel 4. Hasil perhitungan koefisien-koefisien jalur pada model struktural

\begin{tabular}{lccc}
\hline Variabel & Koefisien jalur & Standard Error & T-Statistik \\
\hline Pelatihan $\rightarrow$ Kohesivitas & 0,751435 & 0,044670 & $16,822061^{*}$ \\
\hline$\left.{ }^{*}\right)$ signifikan, $\mathrm{db}=42$, (alpha 0.05$)$ & & &
\end{tabular}

Tabel 5. Hasil perhitungan koefisien-koefisien jalur pada model struktural

\begin{tabular}{lccc}
\hline Variabel & Koefisien jalur & Standard Error & T-Statistik \\
\hline Pelatihan $\rightarrow$ Kinerja & 0,279632 & 0,087914 & $3,180727^{*}$ \\
Kohesivitas $\rightarrow$ Kinerja & 0,562218 & 0,083524 & $6,731228^{*}$ \\
\hline
\end{tabular}

${ }^{*}$ ) signifikan, $\mathrm{db}=42$, (alpha 0.05) 
Nilai koefisien jalur pada variabel pengaruh kohesivitas terhadap kinerja pengajar, yaitu 0,562218 , nilai ini tergolong besar. Pada penelitian ini tingkat kohesivitas pengajar seperti yang telah diuraikan pada pembahasan sebelumnya yaitu tergolong tinggi bila dikaitkan dengan aspek tugas. Hal ini tergolong baik, dibuktikan dengan nilai koefisien jalur yang tinggi dan t-statistik yang signifikan memengaruhi variabel kinerja pengajar.

Pada Lembaga Pendidikan XYZ pengajar diwajibkan untuk memiliki action reseach dan projek-projek penelitian lainnya yang berkaitan dengan kegiatan belajar mengajar. Hasil dari kegiatan tersebut kemudian dipresentasi-kan kepada pengajar lainnya untuk didiskusikan dan dikaji lebih lanjut. Hasil dari diskusi tersebut kemudian dirumuskan sebagai metode-metode yang dapat mendukung kegiatan belajar dan mengajar. Metode yang dilakukan pada Lembaga Pendidikan ini dapat meningkatkan kohesivitas dari pengajar. Dengan menggunakan metode ini sesama pengajar diberikan kesempatan untuk bertemu kemudian saling berkomunikasi dan bertukar pendapat. Komunikasi dan kesempatan bertemu antara sesama pengajar ini lah yang membangun terbentuknya kohesivitas pada Lembaga Pendidikan XYZ.

\section{Implikasi Manjerial}

Setelah melakukan analisis pada penelitian ini, diketahui bahwa program pelatihan dapat memengaruhi tingkat kohesivitas dan kinerja pengajar. Kinerja pengajar juga dapat dipengaruhi oleh kohesivitas pengajar. Hasil penelitian menunjukkan program pelatihan yang dilakukan pada Lembaga Pendidikan XYZ dapat meningkatkan keakraban dan keterikatan diantara pengajar sehingga, kohesivitas dapat meningkat. Tingkat kohesivitas tersebut dapat memengaruhi kinerja pengajar. Pada Lembaga Pendidikan XYZ tingkat kohesivitas pada pengajar dinilai tinggi pada aspek tugas namun, dinilai sedang pada aspek sosial.

Lembaga Pendidikan XYZ perlu meningkatkan program pelatihannya pada aspek instruktur pelatihan. Hal ini dikarenakan, responden menilai belum puas terhadap pemilihan instruktur pada program pelatihan di Lembaga XYZ. Dimensi instruktur pada variabel program pelatihan juga merupakan pembentuk variabel tertinggi sehingga, untuk meningkatkan program pelatihan Lembaga Pendidikan ini perlu memperhatikan dari aspek instruktur. Pemilihan instruktur dari sesama pengajar dapat dilakukan oleh Lembaga Pendidikan ini selain sebagai alternatif baru dalam pemilihan instruktur program pelatihan hal ini juga dinilai dapat meningkatkan kohesivitas diantara pengajar. Pemilihan instruktur dari sesama pengajar dapat memberikan kesempatan sesame pengajar untuk berkomunikasi dan berdiskusi sehingga keakraban dapat terbangun.

Keterpaduan dan keterikatan antar individu pada Lembaga Pendidikan XYZ yang tercermin pada kohesivitas perlu ditingkatkan. Penilaian responden terhadap kohesivitas pada aspek kelompok sosial di Lembaga Pendidikan XYZ dinilai sedang. Oleh karena itu, penting bagi Lembaga Pendidikan XYZ untuk melakukan berbagai kegiatan untuk membangun kohesivitas yang lebih baik. Kegiatan tersebut seperti, pelatihan team building maupun family gathering. Program lain yang dapat dilakukan agar aspek sosial dan tugas dapat berjalan dengan baik yaitu dengan membentuk kelompok-kelompok action research. Program action research yang selama ini telah dilakukan pada Lembaga ini, yaitu dilakukan secara personal dengan objek penelitian pada kelasnya masing-masing. Dengan melakukan program ini secara berkelompok selain data yang dapat digunakan akan lebih banyak karena dilakukan tidak hanya pada satu kelas manfaat lainya adalah, program ini dapat memberikan kesempatan bagi pengajar untuk saling berkomunikasi. Melalui program ini antar pengajar diberikan kesempatan untuk dapat saling bertemu, bekerja sama, berdiskusi dan bertukar pendapat.

Hasil penilaian responden terhadap kinerja pengajar menunjukkan nilai yang sedang pada dimensi kompetensi kepribadian dan profesionalisme pendidik. Oleh karena itu, Lembaga Pendidikan ini perlu melakukan upaya guna meningkatan kedua kompetensi tersebut. Upaya yang dapat dilakukan adalah dengan melakukan penyelenggaraan program pelatihan dengan materi yang berhubungan dengan kompetensi kepribadian dan profesionalisme dari pendidik. Menurut Pakpahan et al. (2011) program pendidikan dan pelatihan mampu memberikan pengaruh yang positif dan signifikan terhadap kinerja pegawai. Tua et al. (2014) menunjukkan bahwa pendidikan dan pelatihan mengenai konsep diri, disiplin kerja secara simultan dan parsial memiliki pengaruh terhadap prestasi kerja pegawai Kejaksaan Tinggi Sulut. 


\section{KESIMPULAN DAN SARAN}

\section{Kesimpulan}

Hasil penelitian mengenai program pelatihan, kohesivitas dan kinerja pengajar pada Lembaga Pendidikan XYZ, maka dapat disimpulkan Keterpaduan dan keterikatan pengajar dari aspek sosial dan tugas di Lembaga Pendidikan XYZ dinilai sedang. Hal ini ditunjukkan dari penilaian responden terhadap kohesivias di Lembaga Pendidikan XYZ. Upaya yang telah dilakukan Lembaga Pendidikan XYZ untuk meningkatkan keakraban diantara pengajarnya yaitu dengan melakukan pelatihan team building dan kerjasama. Lembaga Pendidikan ini perlu melakukan upaya lain untuk meningkatkan keakraban diantara pengajar dengan dengan membentuk kelompokkelompok action research. Program ini diharapkan dapat menjadi ruang bagi sesama pengajar untuk bertemu, berkomunikasi, dan bertukar pendapat.

Program pelatihan yang diselenggarakan oleh Lembaga Pendidikan XYZ dinilai dapat memengaruhi tingkat kohesivitas pengajar. Namun, Lembaga Pendidikan XYZ perlu meningkatkan kualitas dan pemilihan instruktur pelatihan. Responden menilai kurang puas terhadap pemilihan instruktur pada program pelatihan di Lembaga Pendidikan XYZ.

Program pelatihan dan kohesivitas kelompok mampu memengaruhi kinerja pengajar. Namun, kinerja pengajar bukan hanya dipengaruhi oleh faktor program pelatihan dan kohesivitas kelompok saja. Kinerja pengajar juga dipengaruhi oleh faktor lain diluar model pengukuran pada penelitian ini. Kinerja pengajar di Lembaga Pendidikan XYZ dinilai sedang pada aspek kompetensi kepribadian pendidik dan profesionalisme. Oleh karena itu, perlu dilakukan program pelatihan untuk meningkatkan kedua kompetensi tersebut.

\section{Saran}

Penelitian selanjutnya dapat memperluas objek penelitian sehingga memiliki sebaran data yang lebih baik. Dalam upaya peningkatan kinerja terdapat faktor lain selain pelatihan dan kohesivitas. Sehingga, perlu dilakukan penelitian selanjutnya untuk menguji faktorfaktor tersebut.

\section{DAFTAR PUSTAKA}

Aboazoum HME, Nimran U, Al Musadieq M. 2015. Analysis factors affecting employees job performance in Libya. Journal of Business and Management 17(7):42 - 49.

Banwo AO, Du J, Onokala U. 2015. The impact of group cohesiveness on organizational performance: The Nigerian case. International Journal of Business and Management 10(6): 146 - 154. https://doi. org/10.5539/ijbm.v10n6p146.

Carron AV, Eys MA, Lougheed T, Bray SR. 2009. Development of a cohesion questionnaire for youth: the youth sport environment questionnaire. Sport and Exercise Psychology 31:390-480. https://doi.org/10.1123/jsep.31.3.390.

Dahmiri, Sakta K. 2014. Pengaruh pelatihan terhadap kinerja pegawai dinas Pendidikan Kabupaten Sarolangun. Mankeu 3(1): 374 - 463.

[Ditjen PMPTK] Direktorat Jendral Peningkatan Mutu Pendidik dan Tenaga Kependidikan Departemen Pendidikan Nasional. 2008. Penilaian Kinerja Guru. Jakarta: Direktorat Tenaga Kependidikan.

Ghozali I. 2011. Structural Equation Model Metode Alternatif dengan Partial Least Square. Semarang: Badan Penerbit Undip.

Julianry A, Syarief R, Affandi MJ. 2017. Pengaruh pelatihan dan motivasi terhadap kinerja karyawan serta kinerja organisasi kemetrian komunikasi dan informatika. Jurnal Aplikasi Bisnis dan Manajemen 3(2): 236 - 245. https:// doi.org/10.17358/jabm.3.2.236.

Krikpatrick DL. 2006. Evaluating Training Programs: The Four Levels. San Francisco: Berrett-Koehler Publishers, Inc.

Nasir M, Isjoni, Natuna D. 2017. Hubungan antara kohesifitas dan iklim organisasi dengan kinerja kepala sekolah SD Negeri di Kabupaten Siak. Jurnal Manajemen Pendidikan 5(1):1 - 5.

Noviati NP, Zipi NP. 2013. Pengaruh pelatihan outbond terhadap peningkatan kohesivitas tim tenaga Pendidikan. Jurnal Intervensi psikologi JIP 5(2): 1 - 17. https://doi.org/10.20885/ intervensipsikologi.vol5.iss2.art1.

Pakpahan ES, Siswidiyanto dan Sukanto. 2011. Pengaruh pendidikan dan pelatihan terhadap kinerja pegawai studi pada Badan Kepegawaian Daerah Kota Malang. Jurnal Administrasi Publik (JAP) 2(1):116 - 121. 
Palupi YE, Maarif S, Affandi J. 2017. Efektivitas pelaksanaan program dinamika kelompok pada Diklat Fungsional Auditor. Jurnal Aplikasi Bisnis dan Manajemen 3(1): 23-34. https://doi. org/10.17358/jabm.3.1.23.

Purwaningtyastuti, Wismanto B, Suharsono M. 2012. Kohesivitas kelompok ditinjau dari komitmen terhadap organisasi dan kelompok pekerjaan. Prediksi Kajian Ilmiah Psikologi 2(1): 179182.

Sahanggamu PM, Mandey SL. 2014. Pengaruh pelatihan kerja, motivasi, dan disiplin kerja terhadap kinerja karyawan PT. Bank Perkreditan Rakyat Dana Raya. Jurnal EMBA 2(4): 514523.

Setiawati AN dan Riyono B 2018. Pengaruh Pelatihan Komunikasi Interpersonal terhadap Kohesivitas Kelompok pada Divisi Food and Beverage Product Hotel X Bintang 5 Yogyakarta. Jurnal Ilmiah Psikologi Terapan 6(1): 41-53. https:// doi.org/10.22219/jipt.v6i1.4560.

Tua AG, Tewal B, Karuntu M. 2014. Konsep diri, Pendidikan dan pelatihan, disiplin kerja terhadap prestasi kerja pegawai di Kejaksaan tinggi Sulawesi Utara. Jurnal EMBA 2(1): 353-362.

Tuhumena FMB, Kojo C, Worang FG. 2017. Pengaruh pelatihan dan motivasi kerja terhadap kinerja karyawan pada PT. Pegadaian (PERSERO) Kantor Wilayah V Manado. Jurnal EMBA 5(2): 2124-2133.

Widiantoro D, Sukarti, Budiharto S. 2017. Pelatihan komunikasi interpersonal untuk meningkatkan kohesivitas kelompok pada karyawan Hotel $\mathrm{X}$ Yogyakarta. Jurnal Intervensi Psikologi 9(2): 155-168. https://doi.org/10.20885/ intervensipsikologi.vo19.iss2.art2.

Wiratama INJA, Sintaasih DK. 2013. Pengaruh kepemimpinan, diklat, dan disiplin kerja terhadap kinerja karyawan PDAM Tirta Manguntama Kabupaten Badung. Jurnal Manajemen, Srategi Bisnis, dan Kewirausahaan 7(2): 126-134.

Yamin S, Kurniawan H. 2009. Structural Equation Modeling: Belajar Lebih Mudah Teknik Analisis Data Kuesioner dengan Lisrel. Jakarta: Penerbit Salemba Infotek. 